\title{
APRESENTAÇÃO
}

\section{DOSSIÊ: OS ESTADOS UNIDOS NA HISTORIOGRAFIA BRASILEIRA}

\section{Roberto Moll* \\ Flávio Limoncic**}

Durante o Império, mas sobretudo após a proclamação da República, diversos de nossos estadistas, homens de letras e acadêmicos atribuíram aos Estados Unidos lugar de referencial civilizatório a ser emulado ou rejeitado pelo Brasil. Basta pensarmos nas reflexões de Tavares Bastos sobre o federalismo, em Eduardo Prado, para quem a Constituição de 1891 seria planta exótica em nosso solo, e Rui Barbosa, cujo fascínio pelas instituições norte-americanas levou-o a inscrevê-las nesta mesma Constituição. Ao longo do século XX, o cenário não foi diferente. O entusiasmo de Monteiro Lobato por Henry Ford, o país legal e o país real de Oliveira Viana, o pensamento cepalino e as teorias da modernização e da dependência, por exemplo, continuaram a atribuir, para o bem ou para o mal, centralidade aos Estados Unidos no desenho dos destinos do Brasil, fato que acabaria por ganhar dimensões politicamente mais sensíveis durante a Guerra Fria. Para alguns, os Estados Unidos teriam assumido, então, o papel de defensores da democracia enquanto, para outros, tornaram-se promotores do autoritarismo na América Latina.

No campo da cultura não foi diferente. Boa parte da consciência histórica do século XX, ao menos no Ocidente, recebeu a contribuição decisiva da indústria cultural norte-americana. Hollywood, em particular, forjou projetos de vida, hábitos de consumo e ideias de felicidade centrados no American Way of Life com uma capilaridade e poder de sedução sem paralelo. A fascinação dos brasileiros pelo automóvel - ainda que as cidades brasileiras não permitam a experiência da velocidade, da livre circulação e da sensibilidade do deslocamento, tão caras ao projeto societário norte-americano - não deixa de constituir excelente exemplo de tal capilaridade e poder.

Causa perplexidade, portanto, o fato de a história e a historiografia dos Estados Unidos serem tão pouco conhecidas entre nós. Como compreender a principal potência do pós-Segunda Guerra, sua economia, cultura, poder militar, projeção internacional, sem compreender sua sociedade e sua história? Felizmente, nos últimos anos o interesse e as pesquisas sobre os Estados Unidos ganharam fôlego no Brasil. Pesquisadores brasileiros da área de estudos norte-americanos têm proposto abordagens mais matizadas do que as que giravam em torno do referencial civilizatório, enfatizando a complexidade da sociedade norte-americana e das relações entre os Estados Unidos e o Brasil. Nas páginas seguintes, mostraremos a vitalidade e capacidade de renovação do campo de estudos norte-americanos, trazendo artigos de jovens pesquisadores, graduados, mestres e doutores.

É preciso ressaltar, porém, que vitalidade e renovação se fazem em solo bem adubado, como evidencia Cecília Azevedo, professora aposentada da Universidade Federal Fluminense e pioneira nos estudos norte-americanos no Brasil. Na entrevista que compôe o dossiê, Cecília

\footnotetext{
* Doutor em Relações Internacionais (UNESP, UNICAMP, PUC-SP) pela Universidade Estadual Paulista Júlio de Mesquita Filho, Brasil. Professor de História da América II da Universidade Federal Fluminense.

** Doutor em História Social pela Universidade Federal do Rio de Janeiro. Professor Associado da Universidade Federal do Estado do Rio de Janeiro.
} 
Azevedo fala sobre as origens e o desenvolvimento dessa área de estudos, aborda a contradição entre a importância histórica dos Estados Unidos e as poucas pesquisas e obras traduzidas sobre o país no Brasil e reflete sobre o impacto do cinema norte-americano na construção da consciência histórica sobre os Estados Unidos no Brasil, dentre outros temas.

Começamos nosso passeio com o artigo O profeta e o livro sagrado do livre mercado: Hayek e ' $O$ Caminho da Servidão nos Estados Unidos', de Gabriel da Fonseca Onofre. Neste artigo, o jovem doutor e professor do Colégio Pedro II analisa o impacto da obra do filósofo austríaco Friedrich Hayek na construção de uma agenda crítica aos programas do New Deal, que o Governo de Franklin Delano Roosevelt (1933 - 1945) idealizou para superar a crise de 1929, e para o desenvolvimento de uma rede internacional de "Think Tanks" responsáveis pela propagação de ideias em defesa do capitalismo e do liberalismo econômico no século XX.

Os embates entre a direita e a esquerda norte-americana em torno do liberalismo é o tema do artigo Esquerda e Direita se encontram nas páginas da revista "Left and Right: A journal of the libertarian Thought”, fruto do Trabalho de Conclusão de Curso de Vinicius Patrocínio Pereira Costa. O jovem pesquisador analisa o surpreendente movimento de aproximação da direita libertária norte-americana, herdeira dos preceitos do Estado enxuto e do livre mercado, com os grupos da Nova Esquerda nos anos 60. Para isso, Vinicius analisa a principal publicação libertária responsável por consolidar a improvável aliança.

Continuando nos debates sobre os anos 1960, Bárbara Mitchell apresenta o artigo Pobreza nos Estados Unidos: Debates Intelectuais. A doutoranda pelo Programa de Pós-Graduação em História Social da Universidade Federal do Rio de Janeiro pesquisa a relação entre os debates sobre o fenômeno da pobreza e as políticas públicas no país que é símbolo de riqueza e prosperidade.

Dos debates sobre a pobreza passamos para os discursos sobre os problemas dos Estados Unidos baseados na tradição do excepecionalismo norte-americano em: As Teorias Conspiratórias nos Estados Unidos: do Citærens Councils e da JBS a Donald Trump, os jovens professores doutores Ariel Finguerut e Marco Aurélio Dias de Souza analisam duas importantes organizações políticas dos Estados Unidos para compreender a trajetória da retórica e das propostas de Donald Trump.

Por fim, Flávio Henrique Lino encerra o dossiê com o artigo A nova aliança de Abraão: elementos estratégicos do apoio dos Estados Unidos a Israel na revista Foreign Affairs (1945-1975). O jornalista e mestre em História investiga a construção e manutenção do apoio dos Estados Unidos a Israel a partir dos argumentos sobre estratégia e defesa na revista Foreign Affairs. Lino identifica argumentos diferentes e contraditórios na mesma publicação entre 1945 e 1975, a fim de mapear e examinar o debate entre os defensores e os detratores da aliança entre EUA e Israel em meio a Guerra Fria.

Desejamos a todos uma boa leitura! 